\title{
Is microclimate-driven turnover of dung beetle assemblage structure in regenerating coastal vegetation a precursor to re-establishment of a forest fauna?
}

Adrian L.V. Davis $^{\mathrm{a} 1} \cdot$ Rudi J. van Aarde $^{2} \cdot$ Clarke H. Scholtz $^{1} \cdot$ Robert A.R. Guldemond $^{2} \cdot$ Johan Fourie $^{2} \cdot$ Christian M. Deschodt ${ }^{1}$

${ }^{1}$ Scarab Research Unit and ${ }^{2}$ Conservation Ecology Research Unit, Department of Zoology \& Entomology, University of Pretoria, Private Bag X20, Hatfield, 0028 South Africa

Dr Adrian L.V. Davis

Scarab Research Unit,

Department of Zoology \& Entomology

University of Pretoria

Private Bag X20

HATFIELD

0028 South Africa

e-mail: adavis@zoology.up.ac.za

Tel. 0027124202539 (landline)

Tel. 0027781758441 (mobile)

Fax. 0027123625242

${ }^{\mathrm{a}}$ Corresponding author 
Abstract We questioned the capability of post-mining rehabilitation and successional changes in coastal vegetation to achieve restoration of dune forest, dung beetle assemblages in the Maputaland Centre of Endemism, South Africa. A repeat 2010 study of structural turnover between dung beetle assemblages across a 33 year successional sere of rehabilitating vegetation and old-growth forest ( $>73$ years) produced comparable results to an earlier study across the 23 year chronosequence of 2000. Despite overlap, three structural patterns along the 33 year chronosequence were associated with specific stages of vegetation succession and their characteristic microclimates as in 2000. Although species biased to unshaded habitat dominated the earliest succession, there was rapid re-establishment of dominance by shade-associated forest species. In concert with progression from unshaded, post-mining vegetation to strongly shaded, early successional, Acacia shrub-woodland, there was an initial increase in similarity of the dung beetle fauna (species-poor, low abundance) to that in strongly-shaded forest (also species-poor, low abundance). However, in concert with decreasing shade cover in late successional woodland, the dung beetle fauna became species-rich with high abundance so that the early successional trajectory of increasing similarity to forest fauna either levelled off to a plateau (species in 2000; abundance in 2010) or declined (species in 2010, abundance in 2000). It remains to be seen if gaps forming in the oldest Acacia woodland permit forest tree saplings of the exposed understorey to recreate a forest canopy that would be tracked by dung beetles to re-establish a typically speciespoor, deep shade, forest assemblage with low abundance.

Key words: Acacia karroo woodland; chronosequence; dung beetle; dune forest; patchiness; restoration; Richards Bay; Scarabaeinae; succession

\section{Introduction}

Ecological succession drives vegetation recovery after disturbances (Townsend 2007; Grainger and van Aarde 2012a). In general, secondary succession follows a predictable pattern of turnover where community composition and structure change with time as plant and animal species that dominate early seral stages give way to species typical of later seral stages (Wang 2002; Hopp et al. 2010; Taki et al. 2010). Efforts to determine the precise nature, timescales, and processes responsible for successional changes have generated a multitude of restoration studies in different ecotypes. These include long-term monitoring of post-mining, dune forest restoration at Richards Bay in South Africa where various patterns have been demonstrated for progression towards or away from convergence with the biota of old-growth forest (Wassenaar et al. 2005). Results for different taxa may vary according to the quality of the resource that they are tracking across the succession. The diversity of insect species that feed on plants may increase in a unimodal linear progression towards convergence with those in old-growth forest in concert with the increased species richness of woody plants recorded across the succession by van Aarde et al. (1996a). Other vegetative qualities such as density of shade cover may show a bimodal linear progression across the succession, i.e. unshaded grassland; dense, strongly shaded shrub-woodland; less shaded woodland; dense, strongly shaded, oldgrowth forest. Therefore, in insects that respond to shade cover rather than plant species composition, this may generate patterns of early successional faunal response that progress towards then away from convergence such as those yielded by a study on dung beetles across a 23 year chronosequence in 2000 (Davis et al. 2003). Such 
variability in patterns led to questions on the capability of successional processes to achieve restoration of dune forest dung beetle assemblages. Therefore, the present repeat study examines patterns after 33 years at a time when there is further decline in canopy cover.

The study area is located in the Maputaland Centre of Endemism (van Wyk 1996). This ecologically diverse region ( $\left.\sim 26734 \mathrm{~km}^{2}\right)$ straddles the borders of Swaziland, southern Mozambique, and northeast KwaZuluNatal, South Africa. One of the regional ecotypes comprises dune forest, which is very limited in extent as it is restricted to a narrow coastal fringe. In places this forest is intensely disturbed through clearing for forestry, development for tourism and informal settlements, or mining for minerals, which entails the removal of all forest vegetation (van Aarde et al. 1996a). At present mining is the only regional disturbance event that is followed by a forest rehabilitation programme (van Aarde et al. 1996b). This provides a platform for studying the regeneration of dune forest and associated assemblages at a range of trophic levels.

Earlier studies across the successional sere of rehabilitating coastal vegetation suggested age-related convergence towards old-growth dune forest in both compositional and structural properties of tree, herb, millipede and bird assemblages (van Aarde et al. 1996b; 1996c; Kritzinger and van Aarde 1998; Redi et al. 2005; Wassenaar et al. 2005). By contrast, trends in small mammal and dung beetle assemblages were contradictory in suggesting either convergence or non-convergence (Ferreira and van Aarde 1997; Davis et al. 2003; Wassenaar et al. 2005). The predicted time scales for compositional convergence with old-growth forest also varied greatly between biota (Wassenaar et al. 2005) and there was aberrant variation in assemblage structure in some regenerating patches (Wassenaar et al. 2007). Despite this variability, Grainger and van Aarde (2012a) concluded that succession does provide a valid explanation for the restoration of forest plant assemblages. However, the spatial configuration of the landscape is also influential as it comprises a mosaic of patches of differing ages, sizes, and degrees of isolation so that limitations on dispersal and habitat suitability may result in the failure of some forest specialist species to colonize and establish in small and/or distant patches (Grainger et al. 2011).

The present study re-examines successional patterns shown by dung beetles in 2010 and compares them with the findings recorded 10 years earlier (Davis et al. 2003). Our previous study showed a partial progression of species composition towards convergence with that in old-growth dune forest, which is negated by the divergence of species abundance structure after an initial strong trend towards convergence. In view of these conflicting results, the 2010 study determines if the post-mining vegetation produces similar responses in assemblage structure to those recorded during 2000. Furthermore, the present study analyzes structural composition of assemblages, identifies points of temporal transition between dominant faunal components, and investigates the degree of structural variation between habitat patches. It also re-examines if these patterns are consistent with the successional age of vegetation and how they are influenced by the development of dense shade cover, its subsequent decline, and the associated microclimatic changes. Given that microclimate was again found to drive dung beetle assemblage structure, it was concluded that despite non-convergent trajectories of similarity between forest and regenerating vegetation, a typical forest assemblage could still be re-established if secondary forest is the end point that follows the current structural changes in late chronosequence vegetation (Grainger and van Aarde 2012b). 


\section{Methods}

Study area

In both 2000 and 2010, sampling was restricted to a narrow $31 \mathrm{~km}$ long coastal strip of dunes north of the port of Richards Bay $\left(28^{\circ} 48^{\prime} \mathrm{S} 32^{\circ} 05^{\prime} \mathrm{E}\right)$, KwaZulu-Natal, South Africa. Some $17 \mathrm{~km}\left(28^{\circ} 36^{\prime} 24^{\prime \prime}\right.$ to $28^{\circ} 43^{\prime} 30^{\prime \prime} \mathrm{S}$; 32 $2^{\circ} 10^{\prime} 56^{\prime \prime}$ to $\left.32^{\circ} 18^{\prime} 24^{\prime \prime} \mathrm{E}\right)$ of this area comprised rehabilitating vegetation patches of known age representing consecutive windows in chronosequential time that pass from grassland to shrubland to woodland with all woody cover dominated by Acacia karroo (Ferreira and van Aarde 1997; Appendix 1, 2). The old-growth Sokhulu Forest $\left(28^{\circ} 30^{\prime} 34^{\prime \prime}\right.$ to $28^{\circ} 31^{\prime} 38^{\prime \prime} \mathrm{S} ; 32^{\circ} 23^{\prime} 33^{\prime \prime} \mathrm{E}$ to $\left.32^{\circ} 23^{\prime} 42^{\prime \prime} \mathrm{E}\right)$, used as a benchmark reference, is situated $12.5-14 \mathrm{~km}$ to the north of the nearest sampled part of the rehabilitating area. The exact age of Sokhulu Forest is unknown although aerial photographs show that it was present in 1937 (Weisser and Marques 1979).

In 2000, three study sites were selected in each of four forest patches (12 study sites) and in each of eight age windows across a 23 year chronosequence of rehabilitating vegetation (24 study sites) (Davis et al. 2002; 2003). In the present 2010 survey, six original study sites in two surviving forest patches were re-sampled (Sokhulu Forest) whereas in 10 age windows across a 33 year chronosequence of rehabilitating vegetation, 18 original study sites were re-sampled (Windows 2-6), six original sites had to be relocated due to re-mining (Window 1) or lack of access (Window 7), and six new, younger sites were added (Windows 9, 10) (Appendix 1).

Sampling and pitfall trap emplacement

For purposes of comparison, the present survey followed a similar design to that used in 2000 (Davis et al. 2002; 2003). The 2010 survey sampled dung beetles from 36 study sites in the two forest patches and ten age windows of rehabilitating vegetation, three study sites per window. As in 2000, five, $5 \mathrm{~L}$ pitfall traps were placed at each study site (top diameter: $20 \mathrm{~cm}$; depth: $19 \mathrm{~cm}$ ). Sampling was conducted over $48 \mathrm{~h}$ from January $21^{\text {st }}$ till January $23^{\text {rd }} 2010$ and samples were collected at the end of each $24 \mathrm{~h}$ period. Traps were baited at circa $12 \mathrm{~h}$ intervals, with 200-250 $\mathrm{mL}$ composite baits of 50\% pig and 50\% cattle dung, which acted as surrogates for dung dropped by the indigenous mammal fauna (Rowe-Rowe 1994). This method provided 360 samples comprising five samples per study site per day and 30 per chronosequence age window or forest patch.

Compared to the earlier survey (Davis et al. 2002; 2003), trap emplacement was the same at all study sites and age windows except in the early succession where, in 2010, traps were placed along pathways cut into the edge of the dense shrubland (Window 9) or woodland (Window 7) rather than primarily in spaces between patches of dense shrubland as in 2000 (Windows 6y, 6o). Despite recommendations for a minimum between-trap distance of $50 \mathrm{~m}$ (Larsen and Forsyth 2005), traps were emplaced $10 \mathrm{~m}$ apart to be consistent with the methods used in 2000. However, no comparisons were made below the scale of study sites, which were a minimum of $0.11 \mathrm{~km}$ and a maximum of $0.96 \mathrm{~km}$ apart within each age window.

Microclimatic and vegetation data

Microclimate was measured in each of the 12 age windows or forest patches simultaneously with sampling. In eight windows, radiant temperature, relative humidity, background light intensity, and shade (ambient) air temperature 
were measured using Onset, Hobo H08-004-02 four channel data loggers that were mounted face up, $1 \mathrm{~m}$ above the soil surface, on support poles. In the two forest patches (Sokhulu Top and Base) and Windows 3 and 5, only relative humidity and ambient temperature were measured using Onset, Hobo H08-007-02 data loggers. These loggers were also attached to support poles, $1 \mathrm{~m}$ above the soil surface.

Microclimatic measurements were made at a frequency of $90 \mathrm{~s}$ for all loggers. Mean daytime data (light intensity, radiant temperature) were calculated from 525 measurements made between $05 \mathrm{~h} 27$ and $18 \mathrm{~h} 33$, which were the first and last readings that registered background light intensity of $>0$ lux on day 1 in unshaded vegetation. Mean values for relative humidity and ambient temperature were based on 960 measurements recorded during each $24 \mathrm{~h}$ trapping period. Proportional shade cover offered by woody vegetation was estimated by eye at each study site except in Window 10, which lacked tall shrubs or trees.

Analysis of dung beetle successional patterns

Ordination was used to classify changes in faunal structure across the successional sere. The analysis was conducted on a $63 \times 36$ data matrix comprising the mean abundances / trap / day of 63 species at 36 study sites. This data matrix was square root transformed and converted to a 36 × 36 correlation matrix. As data for most of the 36 variables (30) did not deviate significantly from normal distributions (Kolmogorov-Smirnov tests), the matrix was subjected to Factor Analysis using Principal Components to extract factors (Statistica 10 - StatSoft Inc 2011). A maximum of four factors was extractable.

As oblique factors are often difficult to interpret, a Hierarchical Analysis of Oblique Factors was conducted (Wherry 1984). Clusters of study sites were defined at the default factor score level of 0.7 and subjected to varimaxnormalized factor rotation through clusters, which enhances patterns of high and low factor loadings, thus maximizing between-cluster separation. A 36 × 36 correlation matrix was created for rotated, oblique factor loadings and a second Factor Analysis was conducted to generate extended orthogonal factors. Correlations $\left(r^{2}\right)$ between extended orthogonal and oblique factors were used to determine the proportion of unique character contributed by primary (P) extended factors within each cluster, and the proportion in common with other clusters, due to shared secondary (S) factors.

Parallels between dung beetle successional patterns, vegetation physiognomy, and microclimate We used GLM one-way ANOVA to compare differences in factor loadings, species richness, abundance, percentage shade cover, and microclimatic factors between clusters. Tests on microclimatic factors were based on mean values recorded during each hour of daylight (light intensity, radiant temperature) or during each hour over $24 \mathrm{~h}$ periods (humidity, ambient temperature).

Patterns of habitat association and biogeographical representation across the succession Changes in dung beetle representation across the successional sere were determined with regard to their habitat associations and biogeographical distribution patterns. Bias of the species to either unshaded or shaded vegetation was classified using Non-Metric Multidimensional Scaling (NMDS). The data matrix comprised 63 species by their 
mean abundances / trap / day in each of the four ordination clusters. The results were used to determine proportional bias of species abundance to shade or non-shaded conditions in each cluster. With modifications, the biogeographical classification of Davis et al. (2002) was used to determine proportional bias within each cluster to three different biogeographical patterns. Modifications were necessary as, during the course of the 2010 study, several species formerly classified as Maputaland endemics (Davis et al. 2002) were discovered to have wider distributions, either northwards along the Mozambique coastline (e.g. Sisyphus sp. cited as S. bornemisszanus Endrödi), or in shaded localities to the south (e.g. Neosisyphus mirabilis (Arrow)) (see Appendices in Supplementary Information).

Comparing dung beetle successional patterns in 2000 and 2010

For dung beetle data recorded in both 2000 (Appendix in Davis et al. 2003) and 2010 (Appendix 3), paired comparisons were made between species composition and species abundance structure in each age window of regenerating vegetation and each of two forest patches. Species composition was compared using the percentage disagreement measure of distance (Statsoft Inc 2011): distance (x, y) $=100\left(\sum\left|x_{i} \neq y_{i}\right| / \mathrm{I}\right)$, in which I is the total number of species and $\sum\left|x_{i} \neq y_{i}\right|$ is the number of instances in which a species is present in one stand and absent from the other. The results are expressed as percentage similarity $(100-$ distance $[\mathrm{x}, \mathrm{y}])$. Species abundance structure was compared using the Steinhaus similarity index (Legendre and Legendre 1983): $\mathrm{S}=2 \mathrm{~W} /(\mathrm{A}+\mathrm{B})$, in which $\mathrm{W}$ is the sum of the smaller numbers in pairs of species abundance data converted to decimal proportions for each stand and in which A (=1) and B (=1) are the total proportional density of the two stands $(=2)$. The results are expressed as percentage similarity (S x 100). These paired comparisons were plotted in chronological order to test for similarity in patterns between stands of similar age in 2000 and 2010.

\section{Results}

Vegetational changes during succession

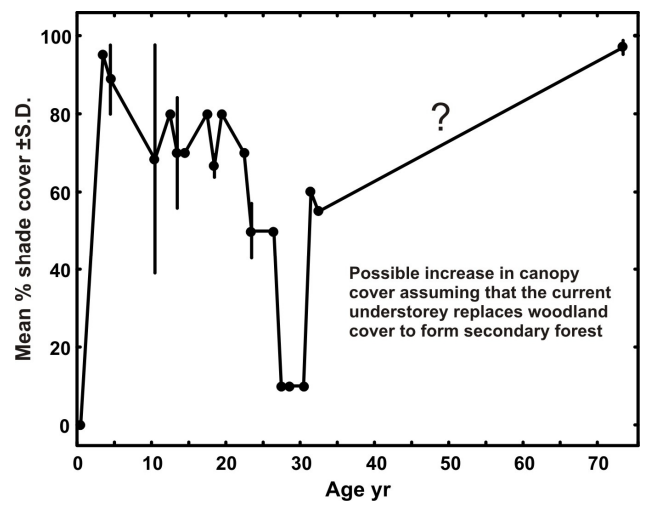

Fig. 1 Percentage shade cover offered by woody vegetation across the 33 year chronosequence and in natural forest. 
Figure 1 summarizes the post-mining successional changes in shade cover offered by woody vegetation at sampling sites. Within a few years, the unshaded grassland of the youngest sites gave way to a dense shrubland cover and then a dense woodland cover, both providing strong shade. Shade cover declined somewhat as the shrubs grew into trees, trunk density thinned, and the canopies of surviving trees expanded over the open understorey. At some sites $>25 \mathrm{yr}$ old, shade cover became much reduced by tree fall exposing the open shrubland of the understorey. These vegetational changes are described in more detail in Appendix 2.

Ordination and faunal successional patterns

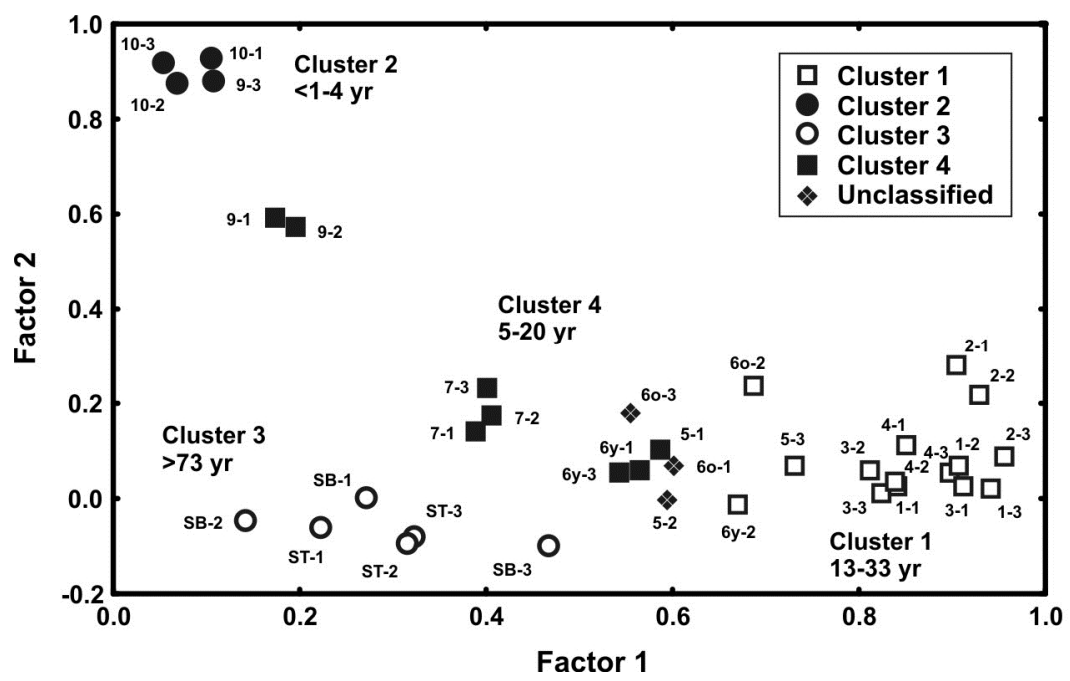

Fig. 2 Ordination plot showing the relative distance between data points representing dung beetle species abundance structure at 36 study sites in 12 vegetation age windows. In sequence, data point labels represent the window identifier (rehabilitating vegetation:10-1; Sokhulu Forest: ST, SB) and study site number (1-3).

The ordination of species abundance patterns (63 species, 50606 individuals) classified the study sites into a maximum of four different clusters (Table 1, Fig. 2). These clusters accounted for $91.8 \%$ of overall variance and represented four different structural patterns that occur in chronosequence although there is temporal overlap and uneven progressions, suggesting some differences in structure between habitat patches (Fig. 3). Each comprised a proportion of unique faunal structure (P1, P2, P3 or P4) and a greater or lesser proportion of two shared faunal influences that either increased (S2) or decreased (S1) from shaded to less shaded vegetation types (Table 2). Greatest unique faunal structure occurred at the endpoints in the unshaded vegetation of the earliest succession (P1) and the oldest shaded vegetation in natural forest (P3), with the intervening successional sere dominated by shared faunal influences (Table 2). 
Table 1 Ordination factor loadings for clusters of study sites with similar dung beetle assemblage structure and GLM one-way ANOVA results for between and within cluster comparisons.

\begin{tabular}{|c|c|c|c|c|c|c|}
\hline & Mean factor loa & adings \pm S.D. (ra & anked in successi & ional sequence) & & \\
\hline & Factor 2 & Factor 4 & Factor 1 & Factor 3 & $F$ & $\mathrm{df}$ \\
\hline Cluster 2 & $0.902 \pm 0.025^{\mathrm{a}}$ & $0.132 \pm 0.163^{b}$ & b $0.085 \pm 0.027^{\mathrm{bc}}$ & ${ }^{c}-0.060 \pm 0.034^{c}$ & $115.812^{* * *}$ & $F_{3,13}$ \\
\hline Cluster 4 & $0.241 \pm 0.219^{b}$ & ${ }^{b} 0.748 \pm 0.062^{a}$ & $0.407 \pm 0.158^{\mathrm{b}}$ & $0.231 \pm 0.158^{\mathrm{b}}$ & $18.361 * * *$ & $F_{3,28}$ \\
\hline Cluster 1 & $0.086 \pm 0.088^{\mathrm{c}}$ & ${ }^{\mathrm{c}} 0.332 \pm 0.131^{\mathrm{b}}$ & b $0.847 \pm 0.090^{a}$ & $0.251 \pm 0.093^{\mathrm{b}}$ & $155.087 * * *$ & $F_{3,56}$ \\
\hline Cluster 3 & $-0.063 \pm 0.038^{c}$ & ${ }^{\mathrm{c}} 0.231 \pm 0.125^{\mathrm{b}}$ & ${ }^{b} 0.290 \pm 0.109^{b}$ & $0.870 \pm \mathbf{0 . 0 8 3}^{\mathrm{a}}$ & $101.339 * * *$ & $F_{3,20}$ \\
\hline Cluster 2 & a & $\mathrm{c}$ & $\mathrm{c}$ & $\mathrm{c}$ & & \\
\hline Cluster 4 & $\mathrm{~b}$ & $\mathbf{a}$ & $\mathrm{b}$ & $\mathrm{b}$ & & \\
\hline Cluster 1 & $\mathrm{c}$ & $\mathrm{b}$ & $\mathbf{a}$ & $\mathrm{b}$ & & \\
\hline Cluster 3 & $\mathrm{c}$ & $\mathrm{bc}$ & $\mathrm{b}$ & $\mathbf{a}$ & & \\
\hline$F_{3,29}$ & $55.347 * * *$ & $34.017 * * *$ & $75.942 * * *$ & $73.179 * * *$ & & \\
\hline
\end{tabular}

Table 2 Correlations of variable oblique factors with secondary $(\mathrm{S})$ and primary $(\mathrm{P})$ extended orthogonal factors (Figs 2,3) ranked in chronological sequence across the succession (*Pearson's $r$ and Coefficient of Determination $\left.\left(r^{2}\right)\right)$.

\begin{tabular}{|c|c|c|c|c|}
\hline \multicolumn{2}{|c|}{$\begin{array}{l}\text { Extended } \\
\text { Factors }\end{array}$} & \multicolumn{2}{|c|}{$\begin{array}{c}\text { Correlation statistics, } r\left(r^{2}\right)^{*} \\
\text { Oblique factors (clusters) }\end{array}$} & \multirow[b]{2}{*}{$\begin{array}{c}\text { Cluster } 3 \\
\text { Shaded forest } \\
>73 \mathrm{yr}\end{array}$} \\
\hline & $\begin{array}{c}\text { Cluster 2 } \\
\text { Grass/shrub }^{\wedge} \\
<1-4 \mathrm{yr}\end{array}$ & 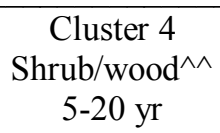 & $\begin{array}{c}\text { Cluster 1 } \\
\text { Open wood^^^ } \\
13-33 \mathrm{yr}\end{array}$ & \\
\hline S1 & $0.05(0.003)$ & $0.75(0.57)$ & $0.84(0.70)$ & $0.77(0.59)$ \\
\hline $\mathrm{S} 2$ & $0.65(0.42)$ & $0.50(0.25)$ & $0.27(0.07)$ & $-0.13(0.02)$ \\
\hline P2 & $0.76(0.57)$ & 0 & 0 & 0 \\
\hline P4 & 0 & $0.42(0.18)$ & 0 & 0 \\
\hline $\mathrm{P} 1$ & 0 & 0 & $0.48(0.23)$ & 0 \\
\hline P3 & 0 & 0 & 0 & $0.62(0.39)$ \\
\hline
\end{tabular}

${ }^{\wedge}$ Three, unshaded, grassland sites and one, $1.3-2 \mathrm{~m}$ tall, shrubland site. ${ }^{\wedge}$ Dense, strongly shaded. ${ }^{\wedge \wedge}$ Open herbaceous to shrubland understorey and moderate shade to much reduced shade through tree fall.

GLM ANOVA tests on ordination loadings suggest that the clusters were well defined (Table 1). All study sites of Window 10 (<1 yr - Cluster 2), Window 7 (10-11 yr - Cluster 4), Windows 4-1 (18-33 yr - Cluster 1), and Sokhulu Forest ( $>73 \mathrm{yr}-$ Cluster 3) were placed within single clusters (Fig. 2). Early successional seres of intermediate age (Window 9 - 4-5 yr) were classified in either Cluster 2 or 4. Later succession seres of intermediate age (Windows 6y, 6o, 5 -12-20 yr) were classified in Clusters 4 or 1, or remained unclassified owing to lack of 
dominance in loadings along any one factor (Factor 2: $0.081 \pm 0.093$; Factor 4: $0.604 \pm 0.032$; Factor 1: $0.585 \pm$ 0.025; Factor 3: $0.370 \pm 0.063$ ). Greatest dominance of loadings along factors occurred within windows for which all study sites were classified in the same cluster (Fig. 3).
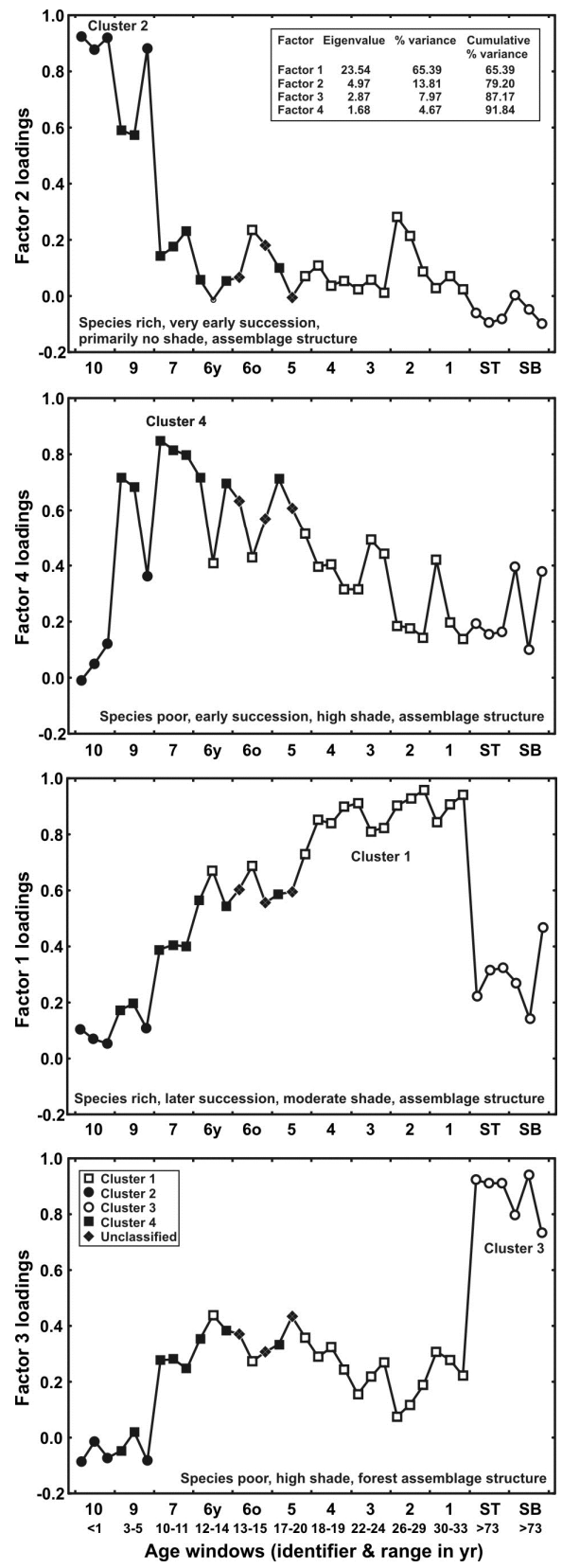

Fig. 3 Patterns of dung beetle assemblage structure across the vegetation chronosequence to natural forest defined by ordination factor loadings. Data points are coded according to the four clusters defined in Figure 2. As far as possible, data points are plotted in chronosequence from Windows 10-1 to Sokhulu Top (ST) to Sokhulu Base (SB). Within windows, sites are plotted in the order: Sites 1, 2, and 3. 
Cluster 2 was characteristic of unshaded, herbaceous vegetation $(<1 \mathrm{yr})$ with minor overlap into the youngest shrubland patch (3-4 yr) (Fig. 2). Coefficients of determination (Table 2) suggest high proportions of unique (P4) and shared elements characteristic of open vegetation (S2). Shared fauna characteristic of shaded vegetation (S1) was poorly represented.

Cluster 4 represented various shrubland and early to mid-successional woodland sites (5-20 yr) (Fig. 2). Proportional variation defined by coefficients of determination (Table 2), suggest limited unique faunal composition (P2). However, there was relatively strong representation by shared elements characteristic of shaded vegetation (S1), particularly at woodland sites (>10 yr) where Factor 1 loadings were higher. There was also appreciable representation by shared elements characteristic of open vegetation (S2), particularly at shrubland sites (4-5 yr) where Factor 2 loadings were higher (Fig. 3).

Cluster 1 comprised closed to open canopy woodland (13-33 yr), whereas Cluster 3 comprised the Sokhulu Forest (>73 yr) (Fig. 2). Proportional variation defined by coefficients of determination, suggest limited unique faunal composition (P1) or appreciable unique faunal composition (P3), respectively (Table 2). However, both clusters included high proportions of shared faunal elements typical of shaded vegetation (S1) and poor representation of those characteristic of unshaded vegetation (S2). Despite the further opening of the late succession woodland canopy at sites $>26 \mathrm{yr}$, only two (Window 2: sites 1,2 ) showed greater proximity to dominant faunal structure at unshaded sites (Factor 2) and greater distance from that at forest sites (Factor 3) (Fig. 3).

Parallels between successional patterns in dung beetles, vegetation physiognomy, and microclimate

The clusters defined by ordination showed clear trends in dung beetle species richness and abundance that paralleled changes in shade cover and microclimate (Table 3). Species richness showed a significant bimodal trend of high values in the less shaded vegetation of the early and late chronosequence (Clusters 2 and 1) and lower values in the more strongly shaded vegetation of the intermediate chronosequence and benchmark forest (Clusters 4 and 3). Abundance showed a significant unimodal trend with values in the late chronosequence (Cluster 1) much higher than those in all other clusters. Differences in light intensity and temperature paralleled variation in shade from woody vegetation. They were highest in the unshaded early chronosequence (Cluster 2), next highest in the moderately shaded late chronosequence (Cluster 1), much or somewhat lower in the intermediate chronosequence (Cluster 4), and lowest in the benchmark forest (Cluster 3). Humidity was the exception in that the significantly highest and lowest values were recorded in the strongly shaded natural forest and strongly shaded intermediate chronosequence, with equally high values in the unshaded early and moderately to poorly shaded, late chronosequence.

Patterns of habitat association and biogeographical representation across the succession

Habitat association and biogeographical affiliation are shown by Figure 4. Species with a bias to less shaded habitat show negative loadings along Dimension 1 and those with a bias to more shaded habitat show positive loadings along Dimension 1. Clear changes in habitat bias and biogeographical composition occurred across the successional sere (Fig. 4, Table 4). 


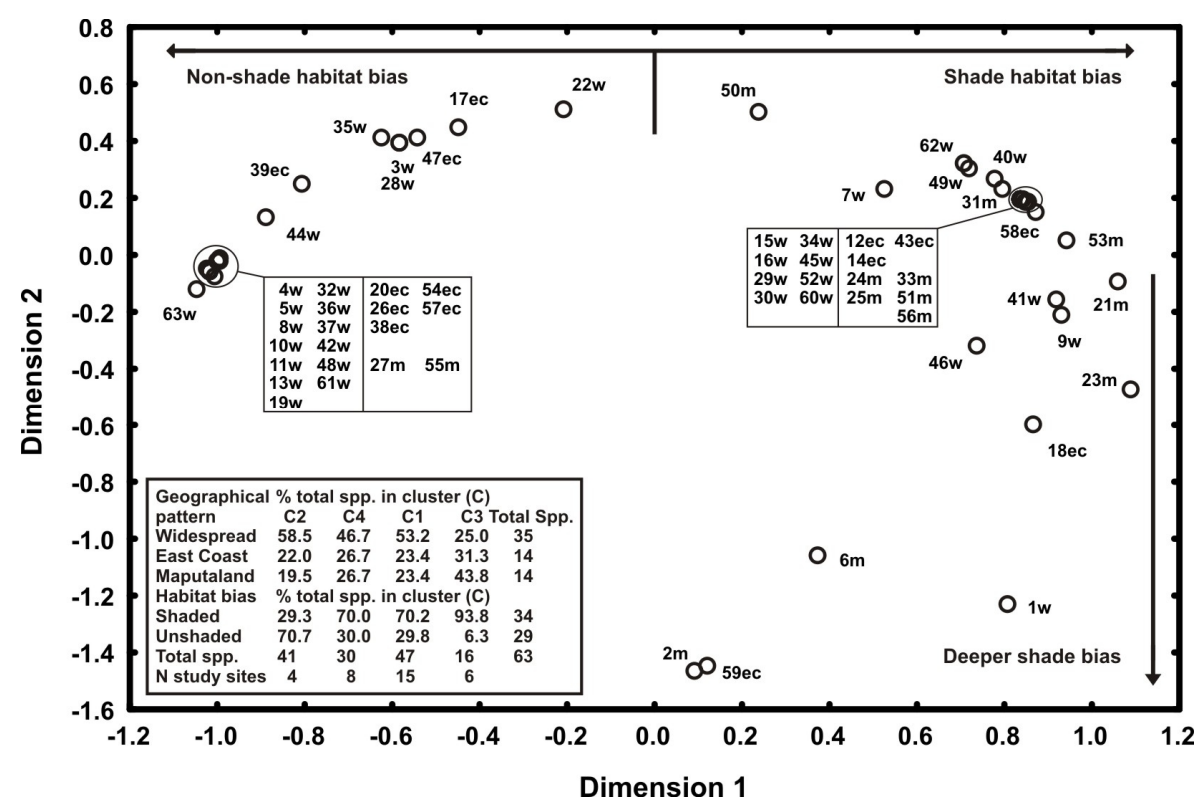

Fig. 4 Ordination plot showing the distances between 63 data points representing dung beetle species abundance distributions between four ordination factors (Appendix 3). The corner table shows the percentage vegetation bias and biogeographical compositions of species in different clusters (C1-C4) (biogeographical classification from Davis et al. (2002) with minor modifications: $\mathrm{m}=$ Maputaland, ec $=$ East Coastal, $\mathrm{w}=$ Widespread distributional bias) (key to species code numbers in Supplementary data, Appendix 3).

Table 3 Mean species richness and abundance for clusters of dung beetle assemblages defined by ordination (Fig. 2) with mean values for associated vegetative shade cover and microclimatic measurements derived from hourly means.

Variables

Mean \pm S.D.

GLM ANOVA

\begin{tabular}{|c|c|c|c|c|c|}
\hline & $\begin{array}{c}\text { Cluster } 2 \\
\text { Grass/shrub^ } \\
<1-4 \mathrm{yr}\end{array}$ & $\begin{array}{c}\text { Cluster } 4 \\
\text { Shrub/wood^ } \\
5-20 \mathrm{yr}\end{array}$ & $\begin{array}{c}\text { Cluster 1 } \\
\text { Open wood }^{\wedge} \\
13-33 \text { yr }\end{array}$ & $\begin{array}{c}\text { Cluster } 3 \\
\text { Shaded forest } \\
>73 \mathrm{yr}\end{array}$ & $F_{3,29}$ \\
\hline Species richness / site & $25.0 \pm 4.9^{\mathrm{a}}$ & $14.3 \pm 4.2^{b}$ & $24.7 \pm 5.2^{\mathrm{a}}$ & $10.3 \pm 2.0^{\mathrm{b}}$ & $21.971 * * *$ \\
\hline Abundance / trap / day & $34.2 \pm 7.0^{\mathrm{b}}$ & $39.4 \pm 23.9^{b}$ & $262.2 \pm 110.7^{\mathrm{a}}$ & $42.7 \pm 21.4^{\mathrm{b}}$ & $22.088 * * *$ \\
\hline$\%$ shade or canopy cover & $23.8 \pm 47.5^{\mathrm{b}}$ & $77.8 \pm 18.2^{\mathrm{ac}}$ & $53.0 \pm 24.3^{b c}$ & $97.0 \pm 1.8^{\mathrm{a}}$ & $9.085 * * *$ \\
\hline Data during daylight & & & & & $F_{2,179}$ \\
\hline Radiant temperature, ${ }^{\circ} \mathrm{C}$ & $32.8 \pm 6.8^{\mathrm{a}}$ & $26.4 \pm 3.9^{\mathrm{b}}$ & $30.8 \pm 7.7^{\mathrm{a}}$ & - & $14.156^{* * *}$ \\
\hline $\begin{array}{l}\text { Light intensity, lux } \\
\mathbf{2 4} \text { h data }\end{array}$ & $43.4 \pm 9.0^{\mathrm{a}}$ & $18.9 \pm 15.6^{\mathrm{c}}$ & $29.7 \pm 22.4^{\mathrm{b}}$ & - & $\begin{array}{c}19.088 * * * \\
F_{3,535}\end{array}$ \\
\hline Ambient temperature, ${ }^{\circ} \mathrm{C}$ & $25.2 \pm 3.5^{\mathrm{a}}$ & $24.1 \pm 2.7^{\mathrm{a}}$ & $24.6 \pm 3.5^{\mathrm{a}}$ & $23.7 \pm 1.6^{\mathrm{b}}$ & $3.310^{*}$ \\
\hline$\%$ humidity & $79.8 \pm 26.1^{\mathrm{b}}$ & $60.0 \pm 25.5^{\mathrm{c}}$ & $86.7 \pm 20.3^{b}$ & $97.7 \pm 4.6^{\mathrm{a}}$ & $77.649 * * *$ \\
\hline
\end{tabular}

$\overline{* P<0.05, * * * P<0.001 \text {; along each row, values followed by a different letter differed significantly, Tukey's HSD. }}$ ${ }^{\wedge}$ See notes under Table 2. 
Microclimatic data:- Cluster 2: site 10-1; Cluster 4: sites 9-1, 7-1, 6y-1; Cluster 1: sites 6o-2, 5-3, 3-3, 2-2, 1-3; Cluster 3: sites ST3, SB3.

There were similar numbers of non-shade (29) and shade-associated species (34) (Fig. 4). However, nonshade association was dominated by widespread species (19) and far outnumbered East Coastal (8) and Maputaland endemics (2). By contrast, shade associated species showed similar numbers of widespread (16) or Maputaland (12) endemics and fewer East Coastal species (6). Proportional representation of widespread species was comparatively high in chronosequence clusters $(\mathrm{C} 1, \mathrm{C} 2, \mathrm{C} 4)$ but extremely low in the forest cluster (C3). Although proportional representation of Maputaland endemics increased in ranked clusters across the succesional sere, it remained similar for the East Coastal species.

Table 4 Proportional biogeographical composition and habitat bias of ordination clusters (Fig. 2) in terms of abundance and results of GLM one-way ANOVA on square root-transformed data.

\begin{tabular}{|c|c|c|c|c|c|}
\hline \multirow[b]{2}{*}{$\begin{array}{l}\text { Distributional } \\
\text { pattern }\end{array}$} & \multicolumn{4}{|c|}{$\%$ abundance / study site \pm S.D. } & \multirow[b]{2}{*}{$F_{329}$} \\
\hline & $\begin{array}{l}\text { Cluster } 2 \\
\text { Grass/shrub^ } \\
<1-4 \text { yr }\end{array}$ & $\begin{array}{c}\text { Cluster } 4 \\
\text { Shrub/wood^ } \\
5-20 \mathrm{yr}\end{array}$ & $\begin{array}{l}\text { Cluster } 1 \\
\text { Open wood^ } \\
13-33 \mathrm{yr}\end{array}$ & $\begin{array}{c}\text { Cluster 3 } \\
\text { Shaded forest } \\
>73 \mathrm{yr}\end{array}$ & \\
\hline \multicolumn{6}{|c|}{ Biogeographical } \\
\hline Widespread & $31.3 \pm 5.6^{\mathrm{a}}$ & $8.9 \pm 4.9^{\mathrm{b}}$ & $15.2 \pm 7.9^{\mathrm{b}}$ & $1.4 \pm 1.6^{\mathrm{c}}$ & $24.493 * * *$ \\
\hline East Coastal & $59.9 \pm 5.0^{\mathrm{a}}$ & $54.9 \pm 13.7^{\mathrm{a}}$ & $20.3 \pm 8.3^{\mathrm{b}}$ & $39.3 \pm 13.9^{\mathrm{a}}$ & $23.427 * * *$ \\
\hline Maputaland & $8.8 \pm 4.4^{\mathrm{c}}$ & $36.3 \pm 17.9^{b}$ & $64.5 \pm 9.9^{\mathrm{a}}$ & $59.3 \pm 13.1^{\mathrm{a}}$ & $30.617 * * *$ \\
\hline \multicolumn{6}{|l|}{ Habitat bias } \\
\hline Shade & $30.8 \pm 12.2^{\mathrm{b}}$ & $93.3 \pm 9.8^{\mathrm{a}}$ & $98.1 \pm 2.6^{\mathrm{a}}$ & $99.9 \pm 0.1^{\mathrm{a}}$ & $114.600 * * *$ \\
\hline Non-shade & $69.2 \pm 12.2^{\mathrm{a}}$ & $6.7 \pm 9.8^{\mathrm{b}}$ & $1.9 \pm 2.6^{\mathrm{b}}$ & $0.1 \pm 0.1^{\mathrm{b}}$ & $114.600^{* * *}$ \\
\hline
\end{tabular}

${ }^{\wedge}$ See notes under Table $2 .{ }^{* * *} P<0.001$; along each row, values followed by a different letter differed significantly, Tukey's HSD.

In terms of abundance, non-shade species outnumbered shade species by two to one in primarily unshaded early successional stages (Cluster 2) (Table 4). By contrast, shade species showed extreme dominance in clusters of later successional stages and the benchmark forest. Proportional abundance of Maputaland endemics increased across the ranked clusters for the successional sere, whereas that of East Coastal species showed a shallow decline, with an appreciably lower value in the late succession woodland (Cluster 1). Proportional abundance of widespread species also declined but followed a bimodal pattern with peaks in the least shaded early and late succession (Clusters 2 and 1).

Similarities between dung beetle faunas of rehabilitating vegetation and natural forest in 2000 and 2010 Paired comparisons were made between dung beetle faunas (species composition (spp.), abundance (ab.)) in benchmark forest and each age window of rehabilitating vegetation in both 2000 and 2010 (Fig. 5). On both occasions, early successional faunas of grassland and low canopy shrubland showed very low similarity to forest faunas followed by increase to moderate (spp. in 2000, ab. in 2010) or high similarity (spp. in 2010, ab. in 2000) in 
shaded shrub / woodland. Late successional patterns in relatively less shaded woodland were variable leveling out (2000 spp., $2010 \mathrm{ab}$.), declining and then leveling out (2010 spp.), or showing a steep decline (2000 ab.). Thus, overall, similarities (Fig. 5), suggest that early succession-associated patterns are age specific, irrespective of the year of study, although later successional patterns were inconsistent, both between years of study and between species composition and abundance.
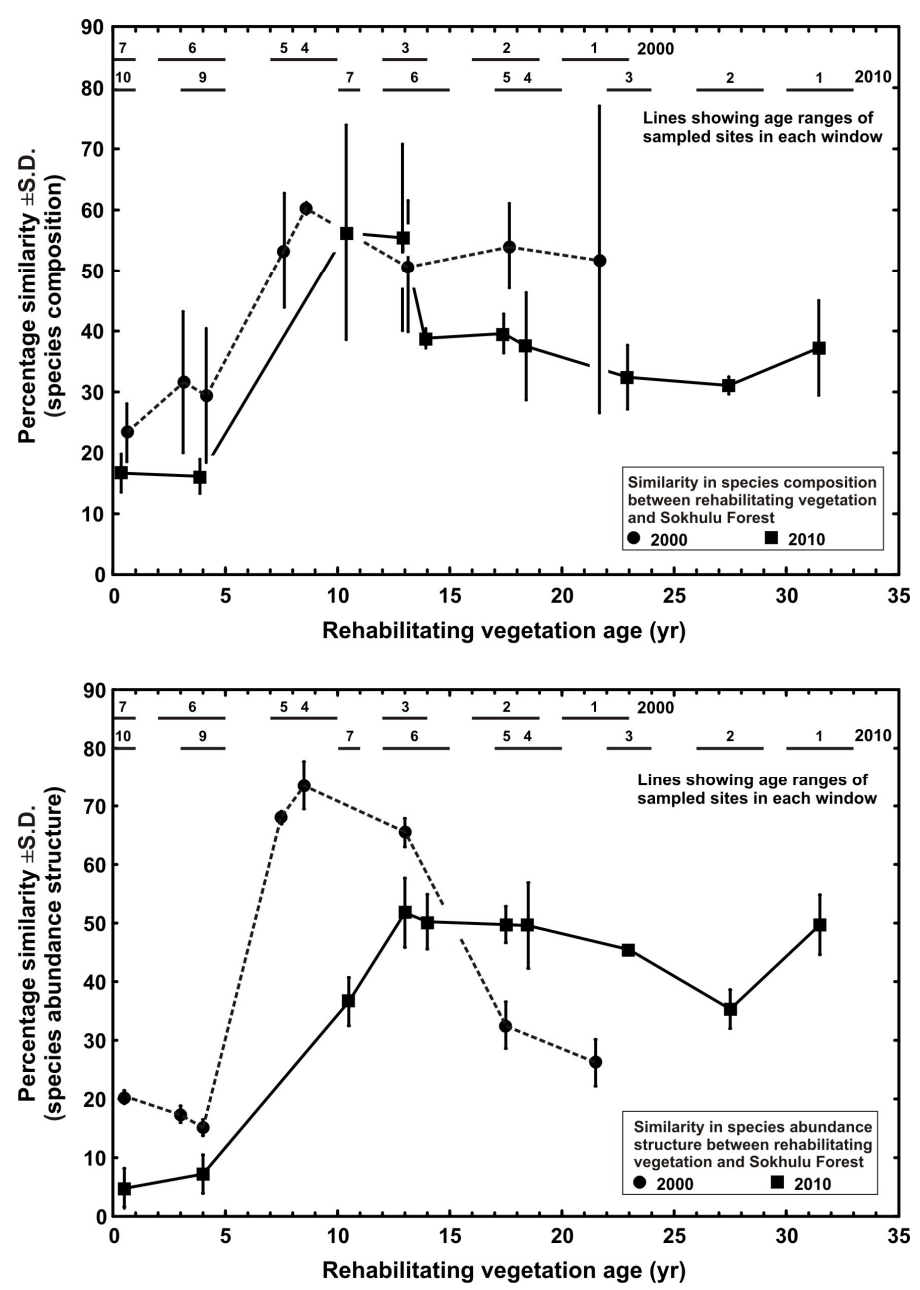

Fig. 5 Similarity of patterns between 2000 and 2010 described by paired comparisons between dung beetle assemblages of age windows in rehabilitating vegetation and each of two reference points in Sokhulu natural forest plotted in chronosequence.

\section{Discussion}

Successional processes and ecological restoration

Over time following complete clearance of vegetation, primary successional processes are considered to lead to restoration of the original ecotype (Townsend 2007; Grainger \& van Aarde 2012a). However, the lengthy time- 
scales predicted for the full restoration of forest (Osho 1996; Hughes et al. 1999; Aide et al. 2000; Wassenaar et al. 2005; Liebsch et al. 2008) suggest that, after 33 years, the chronosequence at Richards Bay remains at an early successional stage. Following turnover from grassland to densely shaded woodland to less shaded open woodland, there is currently extensive canopy loss due to tree fall (Grainger and van Aarde 2012b), which is consistent with the known longevity of 30-40 years for Acacia karroo (Gourlay et al. 1996) that dominates the early succession. A general pattern of primary succession in forest restoration in the Neotropics involves a three stage turnover from grassland to a forest canopy dominated by early successional trees unable to germinate under shade, to a forest canopy dominated by later successional trees able to germinate under the shade of the early succession (Guariguata and Ostertag 2001). In view of this observation, the existence of both convergent and non-convergent trajectories of similarity between forest and age windows of regenerating vegetation shown by various taxa at our study site (Wassenaar et al. 2005), does not necessarily preclude the restoration of dune forest. Similar results for invertebrates of a mined area in Western Australia that track vegetation types, either towards or away from convergence with assemblages in unmined areas (Majer et al. 2007), suggest that such variable trends are a widespread phenomenon.

Potential drivers of dung beetle successional patterns at Richards Bay

From work elsewhere we know that soil texture and vegetation cover (Nealis 1977; Cambefort 1982; Davis 1996), dung type (Davis 1994; Tshikae et al. 2008), dung density (Lobo et al. 2006) and gross amounts available (Lumaret et al. 1992) influence the composition and abundance of dung beetle assemblages. In our 2000 (Davis et al. 2003) and 2010 studies, cross-chronosequential turnover in dung beetle assemblages on deep sands was especially consistent with progressive differences in vegetation structure and their associated microclimates. Trophic variables were probably of lesser importance as coastal dune forest is not ideally suited for mammalian herbivores. However, mammalian dung is available from monkeys, small antelope, and cattle that are illegally herded into the new growth vegetation.

\section{Recovery of forest species at Richards Bay}

All dung beetle species recorded in old-growth dune forest were also recorded within regenerating vegetation with a shaded understorey, bar for one uncommon Onthophagus species, and Gyronotus carinatus, which belongs to a genus with ancient ancestry (Sole and Scholtz 2010). This flightless Maputaland endemic was also absent from a relatively isolated, probably formerly disturbed, forest patch studied by Davis et al. (2002; 2003). Due to flightlessness, it may not be able to re-colonize rehabilitated sites if they are isolated from an undisturbed source forest by disturbed terrain.

Comparisons between cross-chronosequence patterns in 2000 and 2010

Despite progressive thinning of the 22-33 year Acacia woodland canopy due to tree fall and the creation of gaps in the canopy (Grainger \& van Aarde 2012b), largely similar results were generated by both the 2000 (Davis et al. 2003) and 2010 studies on dung beetle assemblages across, respectively, 23 yr and 33 yr chronosequences of regenerating vegetation. Although overall similarity in patterns reflects similar responses to similar microclimate in 
vegetation windows of similar age, there were differences in population structure that were possibly partly related to inter-annual differences in weather conditions. During sampling, beetles active under cooler conditions were more favoured in 2010 (mean ambient temperatures in Window 10: Jan. $21-22=23.2{ }^{\circ} \mathrm{C}$, Jan. $22-23=26.8{ }^{\circ} \mathrm{C}$ ) whereas beetles active under warmer conditions were more favoured in 2000 (mean ambient temperatures at Richards Bay: Jan. $25=31.7{ }^{\circ} \mathrm{C}$, Jan. $26=26.1{ }^{\circ} \mathrm{C}$, Jan. $27=27.8^{\circ} \mathrm{C}$ ). As the local distribution of dung beetles varies with the location of dung and the amounts available (Lobo et al. 2006), their proximity to pitfalls and their likelihood of attraction could also drive differences in population structure between 2000 and 2010.

However, patterns of species richness and abundance were generally comparable. In 2010, species richness followed a bimodal pattern from high to low to high richness across the chronosequence ending in low species richness in forest. This paralleled the bimodal changes in relative shade cover across the successional sere from unshaded to strongly shaded to less shaded chronosequence vegetation to strongly shaded dune forest. By contrast, abundance showed a unimodal pattern from low to high values across the 33 year chronosequence followed by a decrease to low values in natural forest. In 2000, both species richness and abundance followed a bimodal pattern (Davis et al. 2003) although it was less clearly defined than in 2010.

On each occasion, three groups of age windows were defined from dung beetle assemblage structure, representing early succession unshaded vegetation, early succession dense shrub-woodland, and later succession open woodland, all of which differed to structure in a fourth age window represented by natural forest. These four groupings of assemblages result from differences in proportional contribution by four faunal components demonstrated by analysis of the 2010 data. Turnover between dominant components mostly overlapped in time because of environmental patchiness across the chronosequence represented by uneven linear progression between values (Fig. 3). In both 2000 and 2010, changes in dung beetle assemblages were correlated (Davis et al. 2003) or consistent with progressive structural changes in regenerating vegetation and the associated significant changes in microclimate (Davis et al. 2002; Table 3).

There is an initial steep increase in similarity of dung beetle assemblages in chronosequence age windows to those in forest as unshaded vegetation gives way to dense shade but this is followed by declining shade. As natural forest is characterized by dense shade, this decline would be responsible for the plateaux or declines in the trajectories of lines connecting chronosequential values for similarity between dung beetle assemblages of forest and age windows of regenerating vegetation that were variously recorded in 2000 and 2010. However, the lack of a uniform increase in shade cover over time is not necessarily evidential that neither forest nor forest dung beetle faunas will be re-established in the future given that time periods of 70 to $>100$ years have been predicted for recovery in forest ecosystems (Osho 1996; Hughes et al. 1999; Liebsch et al. 2008). Currently, tree fall in the oldest age windows of Acacia woodland is resulting in further reductions in shade-cover. Whilst gaps within age windows from 22 to 33 years are increasing in size, they also show greater stem density of forest tree saplings than under the surviving Acacia canopy (Grainger and van Aarde 2012b). It remains to be seen what future vegetation structure will result from this continuing succession.

Patterns recorded during the 2010 study are probably a better reflection of dung beetle responses to early successional changes than in 2000 as the pitfalls were all placed within the dominant shrubland vegetation (windows 
7,9 ) rather than partly within shrubland and partly in intervening spaces (windows $6 \mathrm{y}, 6 \mathrm{o}$, cited as $\sim 3 \mathrm{yr}$ and $\sim 6 \mathrm{yr}$ old shrubland in 2000) (Davis et al. 2003). However, irrespective of trap placement, early successional faunas showed low similarity to those in natural dune forest in both 2000 and 2010. Thereafter, the rapid re-establishment of dense shaded vegetation drove a relatively steep increase in compositional similarity with the dung beetle faunas of natural forest, similar to patterns observed for dung beetle assemblages in fragmented Neotropical forest (Quintero and Roslin 2005). The late successional decline in shade cover that variously led to plateaux or declines in faunal similarity to forest assemblages may be due to between-occasion differences in beetle population dynamics. In 2000, decline in species abundance similarity resulted primarily from high numbers of a single widespread species, Onthophagus vinctus, in the two oldest age windows. In 2010, relatively fewer O. vinctus were recorded in late successional windows and the overall pattern of similarity to forest hardly declined at all. However, in 2010, tree fall in window 2 resulted in extensive exposure of the understorey, which would increase light intensity. This may be responsible for a slight reduction in similarity between the faunas of Window 2 and densely-shaded, oldgrowth forest. Even so, ordination loadings for the dung beetle assemblages of these gaps in the canopy (window 2, sites 1,2 ) show only limited increase in proximity to those characteristic of unshaded habitats (Factor 2) and only limited increase in distance from those of old-growth forest (Factor 3). Despite the increased abundance of some open area, dung beetle species in these gaps (e.g. Mimonthophagus ambiguus, Onthophagus ursinus), the dense understorey shrubland may provide sufficient shade to exclude most. This minor increase in open area dung beetle species may prove to be a transitory response to decreased shade cover if the canopy is restored by growth of forest tree saplings occupying the gaps,.

Comparisons between habitat and biogeographical associations in 2000 and 2010

Biogeographical composition in different habitats were largely comparable in 2000 (60 spp.) and 2010 (63 spp.). On both occasions, species abundance representation of Maputaland endemics increased across the chronosequence to natural forest, decreased in east coastal taxa, and showed a bimodal pattern in widespread species with peaks in the unshaded early succession and the moderately shaded later succession (Davis et al. 2002; Table 4). Species patterns were only analyzed in this manner in 2010, and showed essentially similar trends except for east coastal taxa which were equally represented across the entire chronosequence. After the re-establishment of woody vegetation, there was a strong turnover from species of unshaded habitat to those characteristic of shaded habitat with an increasing decline in both species representation and abundance of open area taxa towards natural forest. Assemblages from strongly shaded sites with dense Acacia woodland or dense canopy, old-growth forest are both characterized by low species richness and abundance. However, as the classification currently stands, Maputaland endemics are better represented than east coastal species in the cooler forest that is highly humid with moist surface litter. By contrast, east coastal species are better represented than Maputaland endemics in the warmer, early-succession shrubwoodland that is characterized by low humidity and little surface litter. The warmest and least shaded early succession grassland and late succession open woodland showed the greatest concentrations of widespread species.

Conclusions 
The local species pool at our study site north of Richards Bay comprises species with widespread, east coastal or endemic Maputaland distributions. Occurrence and relative abundance of these species in dung beetle assemblages varies according to their responses to microclimate (light intensity, temperature, humidity). Changes in microclimate and dung beetle assemblage structure are induced by differing vegetation structure with increasing age across the chronosequence. Thus, the trajectory of similarity to forest fauna does not proceed as a gradual increase but rather as an increase followed by a decrease that is consistent with transitions from unshaded grassland to dense and deeply shaded shrub/woodland, to less shaded open Acacia woodland, to exposure of the shrubland understorey after the fall of senescent Acacia trees. This non-convergent trajectory does not exclude the re-establishment of a typical dune forest fauna, as most forest species are also present in the woody regenerating vegetation. Therefore, recovery of forest species abundance structure would be dependent only on the re-establishment of forest microclimate. It remains to be seen if young forest trees in the exposed shrubland understorey grow to establish secondary forest.

\section{Acknowledgements}

Dr Matthew Grainger, Alida de Flamingh, Carol Hoole, Cher Lawrence, Tamara Lee, Pieter Olivier, and Laura Owens assisted with the field surveys. Staff and postgraduate members of the University of Pretoria, Scarab Research Unit assisted in sorting samples, particularly Dr Catherine Sole, Dr Power Tshikae, Dr Cornel du Toit, Dr Suko Mlambo, Werner Strümpher, Angelika Switala, and Rentia Tukker. The study was funded through grants to RJvA from Richards Bay Minerals, the Department of Trade and Industry (THRIP), and the National Research Foundation (NRF).

\section{References}

Aide TM, Zimmerman JK, Pascarella JB, Rivera L, Marcano-Veda H (2000) Forest regeneration in a chronosequence of tropical abandoned pastures: implications for restoration ecology. Restor Ecol 8:328338

Cambefort Y (1982) Les coléoptères Scarabaeidae s. str. de Lamto (Côte d'Ivoire): structure des peuplements et rôle dans l'écosystème. Ann Soc Entomol Fr 18:433-459

Davis ALV (1994) Associations of Afrotropical Coleoptera (Scarabaeidae, Aphodiidae, Staphylinidae, Hydrophilidae, Histeridae) with dung and decaying matter: implications for selection of fly-control agents for Australia. J Nat Hist 28:383-399

Davis ALV (1996) Habitat associations in a South African, summer rainfall, dung beetle community (Coleoptera: Scarabaeidae, Aphodiidae, Staphylinidae, Histeridae, Hydrophilidae). Pedobiologia 40:260-280

Davis ALV, van Aarde RJ, Scholtz CH, Delport JH (2002) Increasing representation of localized dung beetles across a chronosequence of regenerating vegetation and natural dune forest in South Africa. Global Ecol Biogeogr 11:191-209

Davis ALV, van Aarde RJ, Scholtz CH, Delport JH (2003) Convergence between dung beetle assemblages of a post-mining chronosequence and unmined dune forest. Restor Ecol 11:29-42 
Ferreira SM, van Aarde RJ (1997) The chronosequence of rehabilitating stands of coastal dune forest: do small mammals confirm it? S Afr J Sci 93:211-214

Gourlay ID, Smith JP, Barnes RD (1996) Wood production in a natural stand of Acacia karroo in Zimbabwe. Forest Ecol Manage 88:289-295

Grainger MJ, van Aarde RJ (2012a) Is succession-based management of coastal dune forest restoration valid? Ecol Restor (in press)

Grainger MJ, van Aarde RJ (2012b) The role of canopy gaps in the regeneration of coastal dune forests. Afr J Ecol (online early)

Grainger MJ, van Aarde RJ, Wassenaar TD (2011) Landscape composition influences the restoration of subtropical coastal dune forest. Restor Ecol 19:111-120

Guariguata MR, Ostertag R (2001) Neotropical secondary forest succession: changes in structural and functional characteristics. Forest Ecol Manage 148:185-206

Hopp PW, Ottermanns R, Caron E, Mayer S, Roß-Nickoll M (2010) Recovery of litter inhabiting beetle assemblages during forest regeneration in the Atlantic forest of Southern Brazil. Insect Conserv Divers 3:103-113

Hughes RF, Kauffman JB, Jaramillo VJ (1999) Biomass, carbon, and nutrient dynamics of secondary forests in a humid tropical region of Mexico. Ecology 80:1892-1907

Kritzinger JJ, van Aarde RJ (1998) The bird communities of rehabilitating coastal dunes at Richards Bay, KwaZuluNatal. S Afr J Sci 94:71-78

Larsen TH, Forsyth A (2005) Trap spacing and transect design for dung beetle biodiversity studies. Biotropica 37:322-325

Legendre L, Legendre P (1983) Numerical ecology. Elsevier, Amsterdam

Liebsch D, Marques MCM, Goldenberg R (2008) How long does the Atlantic Rain Forest take to recover after a disturbance? Changes in species composition and ecological features during secondary succession. Biol Conserve 141:1717-1725

Lobo JM, Hortal J, Cabrero-Sañudo FJ (2006) Regional and local influence of grazing activity on the diversity of a semi-arid dung beetle community. Divers Distrib 12:111-123

Lumaret JP, Kadiri N, Bertrand M (1992) Changes in resources: consequences for the dynamics of dung beetle communities. J Appl Ecol 29:349-356

Majer JD, Brennan KEC, Moir ML (2007) Invertebrates and the restoration of a forest ecosystem: 30 years of research following bauxite mining in Western Australia. Restor Ecol 15:S104-S115

Nealis VG (1977) Habitat associations and community analysis of south Texas dung beetles (Coleoptera: Scarabaeinae). Can J Zool 55:138-147

Osho JSA (1996) Modelling the tree population dynamics of the most abundant species in a Nigerian tropical rain forest. Ecol Model 89:175-181

Quintero I, Roslin T (2005) Rapid recovery of dung beetle communities following habitat fragmentation in central Amazonia. Ecology 86:3303-3311 
Redi BH, van Aarde RJ, Wassenaar TD (2005) Coastal dune forest development and the regeneration of millipede communities. Restor Ecol 13:284-291

Rowe-Rowe DT (1994) The ungulates of Natal. Natal Parks Board, Pietermaritzburg

Sole CL, Scholtz CH (2010) Did dung beetles arise in Africa? A phylogenetic hypothesis based on five gene regions. Mol Phylogenet Evol 56:631-641

StatSoft Inc (2011) Statistica 10. StatSoft Inc., 230 East $14^{\text {th }}$ Street, Tulsa, OK 74104, USA

Taki H, Yamaura Y, Okochi I, Inoue T, Okabe K, Makino S (2010) Effects of reforestation age on moth assemblages in plantations and naturally regenerated forests. Insect Conserv Divers 3:257-265

Townsend CR (2007) Ecological applications: towards a sustainable world. Wiley-Blackwell

Tshikae BP, Davis ALV, Scholtz CH (2008) Trophic associations of a dung beetle assemblage (Scarabaeidae: Scarabaeinae) in a woodland savanna of Botswana. Environ Entomol 37:431-441

van Aarde RJ, Ferreira SM, Kritzinger JJ, van Dyk PJ, Vogt M, Wassenaar TD (1996a) An evaluation of habitat rehabilitation on coastal dune forests in northern Kwazulu-Natal, South Africa. Restor Ecol 4:1-12

van Aarde RJ, Ferreira SM, Kritzinger JJ (1996b) Successional changes in rehabilitating coastal dune communities in northern KwaZulu/Natal, South Africa. Landscape Urban Plan 34:277-286

van Aarde RJ, Ferreira SM, Kritzinger JJ (1996c) Millipede communities in rehabilitating coastal dune forests in northern KwaZulu/Natal, South Africa. J Zool 238:703-712

van Wyk AE (1996) Biodiversity of the Maputaland centre. In: van der Maesen LJG, van der Burgt XM, van Medenbach de Rooy JM (eds) The biodiversity of African plants. Proceedings XIVth AETFAT Congress, 22-27 August 1994, Wageningen, The Netherlands. Kluwer Academic Publishers, Dordrecht, The Netherlands, pp 198-207

Wang GH (2002) Plant traits and soil chemical variables during a secondary vegetation succession in abandoned fields on the Loess Plateau. Acta Bot Sin 44:990-998

Wassenaar TD, van Aarde RJ, Pimm SL, Ferreira SM (2005) Community convergence in disturbed sub-tropical dune forest. Ecology 86:655-666

Wassenaar TD, Ferreira SM, van Aarde RJ (2007) Flagging aberrant sites and assemblages in restoration projects. Restor Ecol 15:68-76

Weisser PJ, Marques F (1979) Gross vegetation changes in the dune area between Richards Bay and the Mfolozi River, 1937-1974. Bothalia 12:711-721

Wherry RJ (1984) Contributions to correlational analysis. Academic Press, New York 
Appendix 1. The location of rehabilitating vegetation divided into windows of similar age, natural forest reference points, and sampling sites (numbered circles) north of Richards Bay, KwaZulu-Natal, South Africa in January 2010 with the year of commencement of rehabilitation for each site.

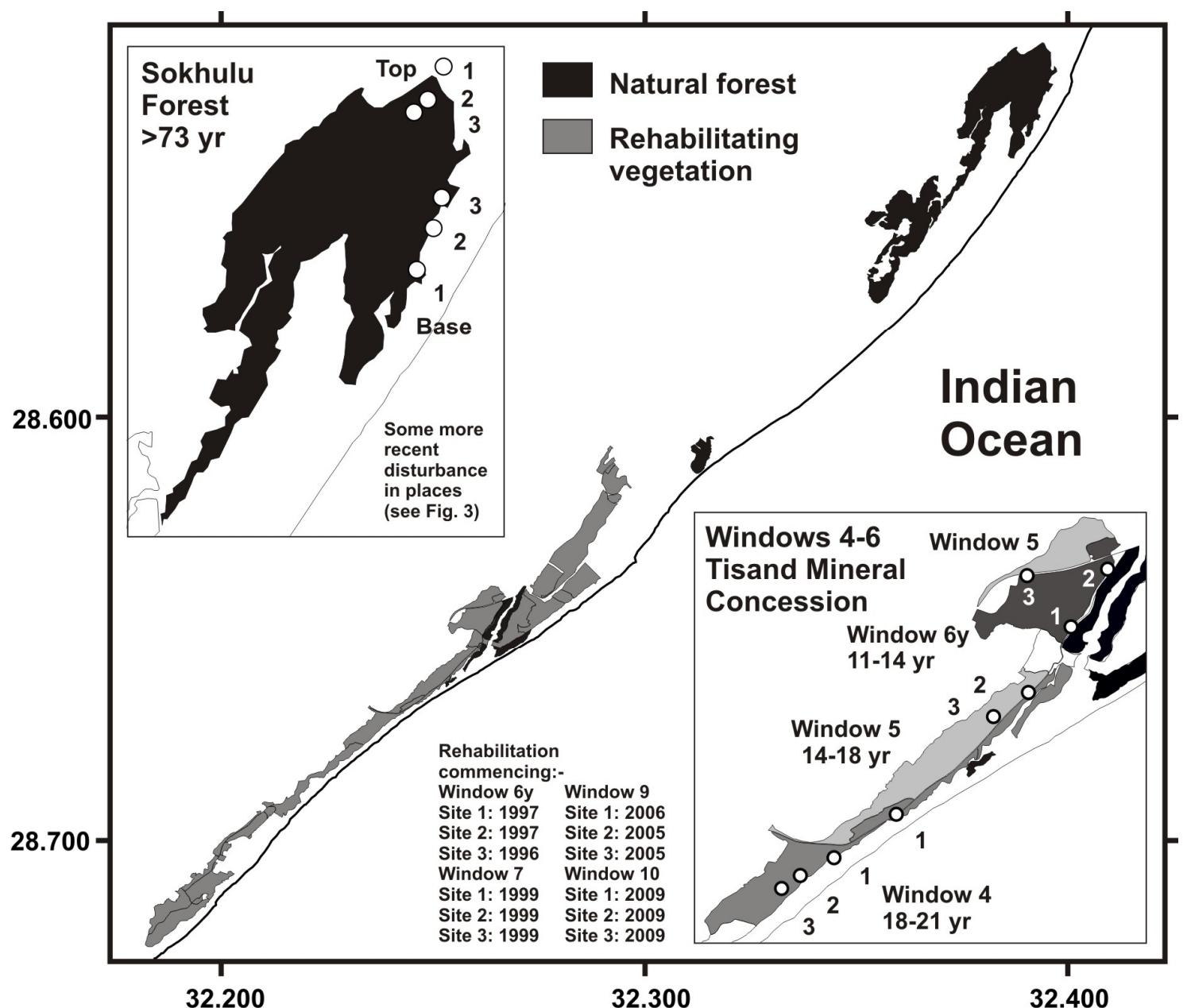

32.200

32.300
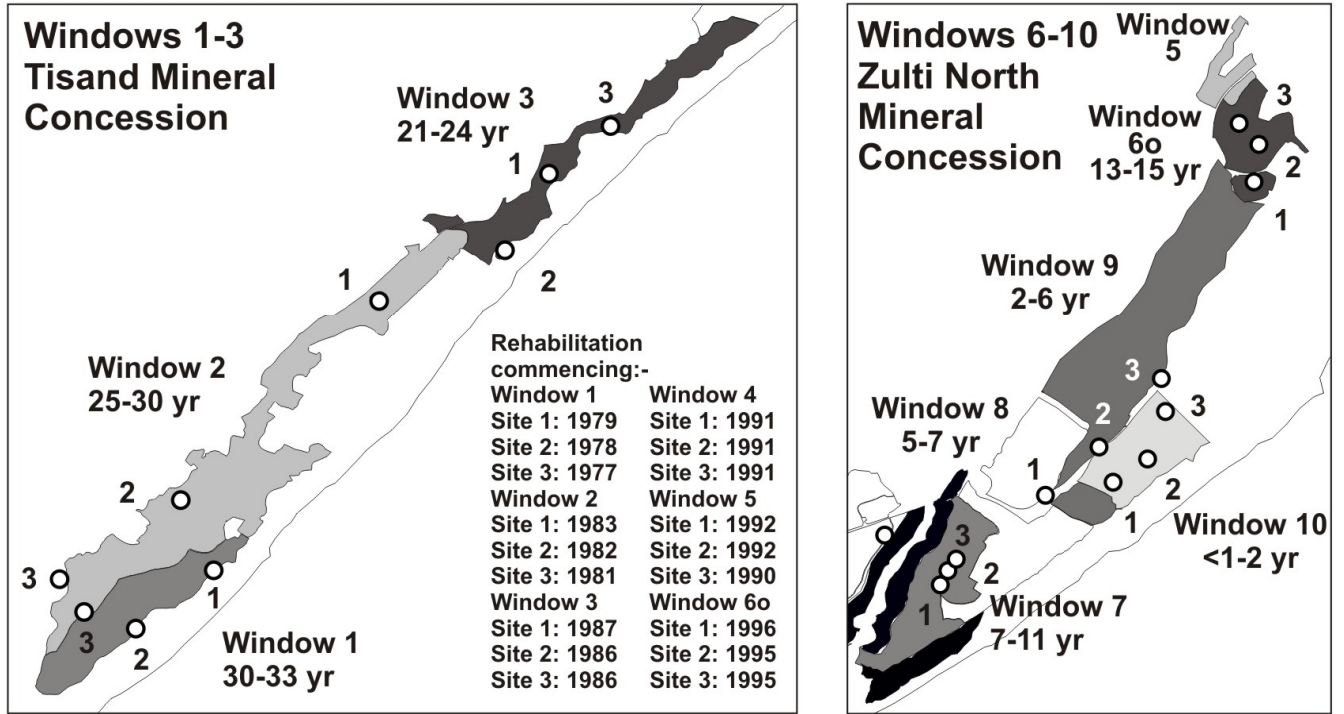
Appendix 2. Brief description of rehabilitation procedures and secondary successional patterns in vegetation following dredge mining at Richards Bay.

Dredge-mining at Richards Bay entails the complete clearance of dune forest in order to extract Titanium minerals from the underlying sand at an on-site processing plant. After processing, the remaining sand is bulldozed to reconfigure the topology of the original dunes. Under terms of the mining contract, one-third of the leased area is rehabilitated to indigenous vegetation. These areas are first covered by topsoil collected prior to mining, fenced by temporary screens, and planted with fast-growing annuals (sunflower, millet) to bind the sand. Thereafter vegetation regenerates spontaneously over time. The early successional sere is dominated by unshaded vegetation in which the planted annuals are replaced by grassland after 6-8 months (van Aarde et al. 1996a). Over the course of the following 1-3 yr, the grasses become shaded by the development of a dense Acacia karroo-dominated shrubland (Ferreira and van Aarde 1997). As the shrubs grow in height over the following 4-9 years, they first form dense $A$. karroo-dominated woodland, which gradually declines in trunk-density as the number of surviving trees is reduced. Over the subsequent 9-15 yr, the density of trunks declines further and the canopies of each tree expand to produce A. karroo woodland with a shaded but open understorey that is colonized by indigenous woody herb, shrub, and tree species typical of dune forests in the region. With increasing age, the understorey cover of woody herbs becomes increasingly characterized by a greater density of shrubs and young forest trees. Open $A$. karroo woodland with an open shrubland and woody herb understorey was characteristic of the oldest 20-23 year stand surveyed during a previous dung beetle study in 2000 (Davis et al. 2002; 2003). After 26-33 years, the oldest stands in 2010 already have many gaps in the canopy due to A. karroo tree fall. Within these gaps, 16 species of young indigenous forest trees were found to show greater density than in the understorey of the surviving Acacia woodland (Grainger andvan Aarde 2012b). It remains to be seen if these saplings grow to fill a restored canopy, thus developing a dune forest typical of the region.

\section{Additional references for Appendix 3.}

Doube BM (1991) Dung beetles of southern Africa. In: Hanski I, Cambefort Y (eds) Dung beetle ecology. Princeton University Press, Princeton, pp 133-155 and 383-387

Paschalidis KM (1974) The genus Sisyphus Latr. (Coleoptera: Scarabaeidae) in Southern Africa. Unpublished M.Sc. Thesis, Rhodes University, Grahamstown, South Africa

\section{Taxonomic and biogeographical note}

It has recently been noted that the type series of Sisyphus bornemisszanus Endrödi comprises two species. The holotype and five paratypes are synonymous with $S$. sordidus Boheman. The allotype and five paratypes are a second species. As this may no longer be called $S$. bornemisszanus (=nomen nudum), the species becomes undescribed and unnamed. It is, therefore, cited as Sisyphus sp. 
Appendix 3. Abundance of 63 dung beetle species recorded near Richards Bay in post-mining vegetation (Windows 10-1) and Sokhulu natural forest.

Species (biogeographical classification)** Average abundance/trap/day in age windows, Sokhulu (Top, ST; Base, SB), or samples defined by ordination cluster C1-C4 (Fig. 2)

\section{CANTHONINI}

Anachalcos convexus Boheman (W)

2. Gyronotus carinatus Felsche (M)

3. Odontoloma ?pauxillum Boheman (W)

SCARABAEINI

4. Kheper lamarcki (Macleay) (W)

5. Pachylomera femoralis (Kirby) (W)

6. Scarabaeus bornemisszai zur Strassen (M)

7. Scarabaeus goryi Castelnau (W)

\section{GYMNOPLEURINI}

8. Allogymnopleurus thalassinus Klug (W)

9. Garreta azureus (Fabricius) (W)

10. Garreta unicolor (Fahraeus) (W)

SISYPHINI

11. Neosisyphus confrater (Kolbe) (W)

12. Neosisyphus mirabilis (Arrow) (EC)

13. Neosisyphus spinipes (Thunberg) (W)

14. Sisyphus sp.* (EC)

15. Sisyphus gazanus Arrow (W)

16. Sisyphus seminulum Gerstaecker (W)

17. Sisyphus sordidus Boheman (EC)

18. Sisyphus sp. y (sensu Paschalidis 1974) (EC) DICHOTOMINI

19. Heliocopris hamadryas (Fabricius) (W) 20. Pedaria sp. III (sensu Doube 1991) (EC)

\section{COPRINI}

21. Catharsius mossambicanus Ferreira*(M)

22. Catharsius tricornutus Degeer (W)

23. Catharsius sp. 1 (M)

24. Copris inhalatus ssp. santaluciae Ferreira (M)

25. Copris urus Boheman (M)

26. Copris puncticollis Boheman (EC)

27. Metacatharsius zuluanus Balthasar* (M)

ONTHOPHAGINI

28. Caccobius cavatus d'Orbigny (W)

29. Caccobius nigritulus Klug (W)

30. Caccobius obtusus Fahraeus (W)

31. Caccobius sp. 1 (M)

32. Caccobius sp. $2(\mathrm{~W})$

33. Caccobius sp. $3(\mathrm{M})$

34. Caccobius sp. 4 (W)

35. Cleptocaccobius viridicollis (Fahraeus) (W)

36. Digitonthophagus gazella (Fabricius) (W)

37. Hyalonthophagus alcyonides (d'Orbigny) (W)

38. Milichus sp. 1 (EC)

39. Mimonthophagus ambiguus (Péringuey)*(EC)

40. Onthophagus aeruginosus Roth (W)

41. Onthophagus bicavifrons d'Orbigny* (W)

42. Onthophagus depressus Harold (W)

43. Onthophagus lacustris Harold (EC)

44. Onthophagus obtusicornis Fahraeus (W)

45. Onthophagus pugionatus Fahraeus (W)

46. Onthophagus quadrinodosus Fahraeus (W)

47. Onthophagus ursinus d'Orbigny (EC)

48. Onthophagus stellio Erichson (W)

49. Onthophagus vinctus Erichson (W)

50. Onthophagus sp. nr fimetarius* (M)

51. Onthophagus sp. nr sugillatus (M)

52. Onthophagus sp. $1(\mathrm{~W})$

53. Onthophagus sp. 2 (M)

54. Onthophagus sp. 3 (EC)

55. Onthophagus sp. 5* (M)

56. Onthophagus sp. 6 (M)

57. Proagoderus aureiceps d'Orbigny (EC)

58. Proagoderus aciculatus (Fahraeus) (EC)

ONITICELLINI

59. Afrodrepanus impressicollis (Boheman)*(EC) 60. Drepanocerus kirbyi Kirby (W)

61. Euoniticellus intermedius (Reiche) (W)

62. Oniticellus planatus Castelnau (W)

63. Liatongus militaris (Castelnau) (W)

$\begin{array}{lllllllll}10 & 9 & 7 & 6 y & 60 & 5 & 4 & 3 & 2\end{array}$

$\begin{array}{llllll}0.00 & 0.37 & 0.03 & 0.13 & 0.00 & 0.00\end{array}$

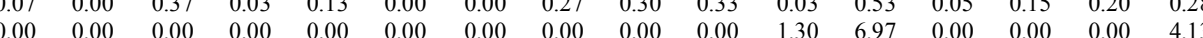

$\begin{array}{llllllllllllllll}0.00 & 0.03 & 0.00 & 0.00 & 0.03 & 0.00 & 0.00 & 0.03 & 0.00 & 0.00 & 0.00 & 0.00 & 0.03 & 0.00 & 0.01 & 0.00\end{array}$

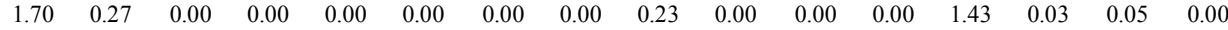

$\begin{array}{llllllllllllllll}1.77 & 0.83 & 0.00 & 0.00 & 0.27 & 0.00 & 0.00 & 0.00 & 0.00 & 0.00 & 0.00 & 0.00 & 1.75 & 0.10 & 0.02 & 0.00\end{array}$

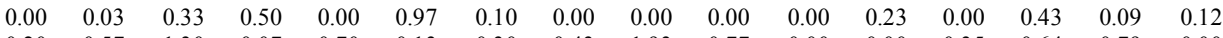

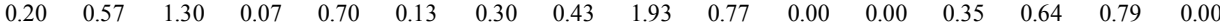

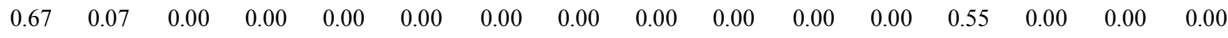

$\begin{array}{llllllllllllllll}0.00 & 0.00 & 0.00 & 0.83 & 0.03 & 0.27 & 0.40 & 0.60 & 0.37 & 0.60 & 0.10 & 0.00 & 0.00 & 0.35 & 0.41 & 0.05\end{array}$

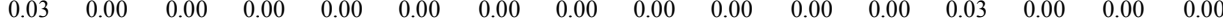

$\begin{array}{llllllllllllllll}0.17 & 0.03 & 0.00 & 0.00 & 0.00 & 0.00 & 0.00 & 0.00 & 0.00 & 0.00 & 0.00 & 0.00 & 0.15 & 0.00 & 0.00 & 0.00\end{array}$

$\begin{array}{rrrrrrrrrrrrrrrr}0.00 & 0.00 & 0.13 & 0.47 & 13.57 & 2.33 & 3.37 & 6.20 & 10.47 & 5.30 & 0.00 & 0.03 & 0.00 & 0.29 & 6.77 & 0.02 \\ 0.53 & 0.03 & 0.00 & 0.00 & 0.00 & 0.00 & 0.00 & 0.00 & 0.00 & 0.07 & 0.00 & 0.00 & 0.43 & 0.00 & 0.01 & 0.00\end{array}$

$\begin{array}{llllllllllllllll}0.53 & 0.03 & 0.00 & 0.00 & 0.00 & 0.00 & 0.00 & 0.00 & 0.00 & 0.07 & 0.00 & 0.00 & 0.43 & 0.00 & 0.01 & 0.00\end{array}$

$\begin{array}{llllllllllllllll}0.00 & 0.00 & 0.00 & 0.00 & 0.33 & 0.00 & 0.23 & 0.20 & 0.60 & 0.07 & 0.00 & 0.00 & 0.00 & 0.00 & 0.23 & 0.00\end{array}$

$\begin{array}{llllllllllllllll}0.00 & 0.00 & 0.00 & 0.20 & 0.90 & 0.20 & 0.50 & 4.43 & 1.60 & 1.93 & 0.00 & 0.00 & 0.00 & 0.06 & 1.88 & 0.00\end{array}$

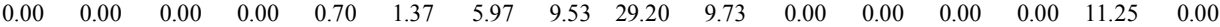

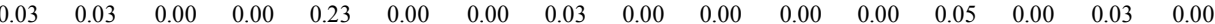

$\begin{array}{llllllllllllllll}0.00 & 0.00 & 0.00 & 0.27 & 15.63 & 0.10 & 0.37 & 2.77 & 2.47 & 6.00 & 1.00 & 3.23 & 0.00 & 0.13 & 2.46 & 2.12\end{array}$

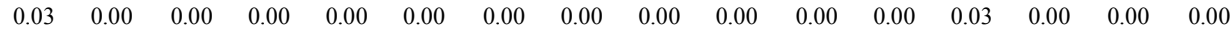

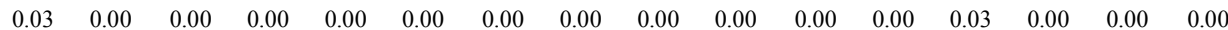

$\begin{array}{llllllllllllllll}0.20 & 0.37 & 1.87 & 2.03 & 8.13 & 1.37 & 5.17 & 5.20 & 4.10 & 3.17 & 1.17 & 1.30 & 0.20 & 1.73 & 4.25 & 1.23\end{array}$

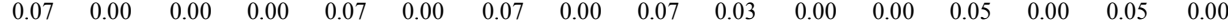

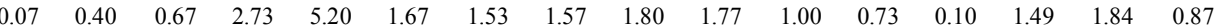

$\begin{array}{llllllllllllllll}0.00 & 0.00 & 0.00 & 0.00 & 0.00 & 0.00 & 0.00 & 0.03 & 0.03 & 0.00 & 0.00 & 0.00 & 0.00 & 0.00 & 0.01 & 0.00 \\ 0.03 & 0.00 & 0.10 & 0.10 & 0.17 & 0.00 & 1.17 & 0.63 & 1.57 & 2.97 & 0.03 & 0.03 & 0.03 & 0.06 & 1.28 & 0.03\end{array}$

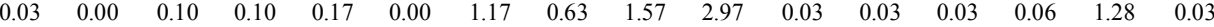

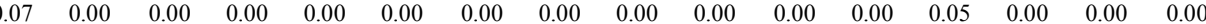

$\begin{array}{llllllllllllllll}1.50 & 0.00 & 0.00 & 0.00 & 0.00 & 0.00 & 0.00 & 0.00 & 0.00 & 0.00 & 0.00 & 0.00 & 1.13 & 0.00 & 0.00 & 0.00\end{array}$

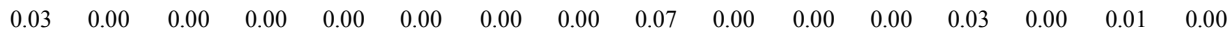

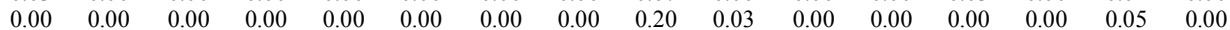

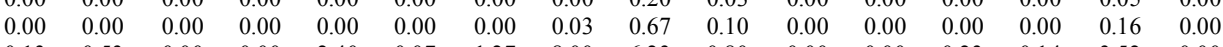

$\begin{array}{llllllllllllllll}0.13 & 0.53 & 0.00 & 0.00 & 2.40 & 0.07 & 1.27 & 8.00 & 6.23 & 0.80 & 0.00 & 0.00 & 0.23 & 0.14 & 3.52 & 0.00\end{array}$

$\begin{array}{llllllllllllllll}0.00 & 0.03 & 0.00 & 0.00 & 0.00 & 0.00 & 0.00 & 0.00 & 0.00 & 0.00 & 0.00 & 0.00 & 0.03 & 0.00 & 0.00 & 0.00\end{array}$

$\begin{array}{lllllllllllllllll}0.07 & 0.00 & 0.00 & 0.67 & 0.60 & 4.83 & 39.00 & 56.37 & 86.93 & 41.00 & 0.07 & 0.10 & 0.05 & 0.44 & 45.55 & 0.08\end{array}$

$\begin{array}{llllllllllllllll}0.00 & 0.00 & 0.00 & 0.00 & 0.00 & 0.00 & 0.00 & 0.03 & 0.17 & 0.17 & 0.00 & 0.00 & 0.00 & 0.00 & 0.07 & 0.00\end{array}$

$\begin{array}{llllllllllllllll}0.07 & 0.03 & 0.00 & 0.00 & 0.00 & 0.00 & 0.00 & 0.00 & 0.13 & 0.00 & 0.00 & 0.00 & 0.05 & 0.01 & 0.03 & 0.00\end{array}$

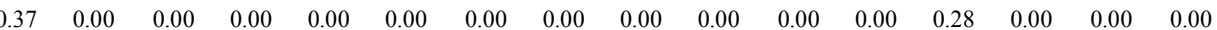

$\begin{array}{lllllllllllllllll}.37 & 0.07 & 0.00 & 0.00 & 0.00 & 0.00 & 0.00 & 0.00 & 0.00 & 0.00 & 0.00 & 0.00 & 0.33 & 0.00 & 0.00 & 0.00\end{array}$

$\begin{array}{llllllllllllllll}4.50 & 2.53 & 0.53 & 0.30 & 3.10 & 0.13 & 0.93 & 0.50 & 3.53 & 0.00 & 0.03 & 0.00 & 4.93 & 0.48 & 1.61 & 0.02\end{array}$

$\begin{array}{llllllllllllllll}0.03 & 0.00 & 0.00 & 0.03 & 0.00 & 0.07 & 1.00 & 0.07 & 0.13 & 0.03 & 0.00 & 0.00 & 0.03 & 0.01 & 0.26 & 0.00 \\ 0.00 & 0.00 & 0.00 & 0.00 & 0.03 & 0.00 & 0.07 & 0.07 & 0.07 & 0.00 & 0.03 & 0.00 & 0.00 & 0.00 & 0.04 & 0.02\end{array}$

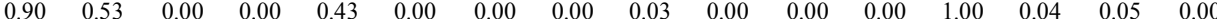

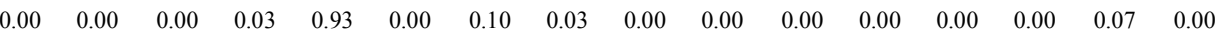

$\begin{array}{llllllllllllllll}0.07 & 0.07 & 0.00 & 0.00 & 0.00 & 0.00 & 0.00 & 0.10 & 0.00 & 0.00 & 0.00 & 0.00 & 0.10 & 0.00 & 0.02 & 0.00\end{array}$

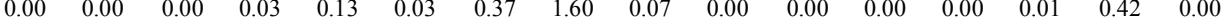

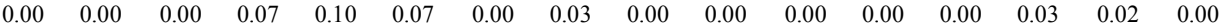

$\begin{array}{llllllllllllllll}7.23 & 1.73 & 0.00 & 0.00 & 0.10 & 0.03 & 1.17 & 0.33 & 15.77 & 1.10 & 0.00 & 0.00 & 6.40 & 0.16 & 3.69 & 0.00\end{array}$

$\begin{array}{llllllllllllllll}0.10 & 0.00 & 0.00 & 0.00 & 0.00 & 0.00 & 0.00 & 0.00 & 0.00 & 0.00 & 0.00 & 0.00 & 0.08 & 0.00 & 0.00 & 0.00\end{array}$

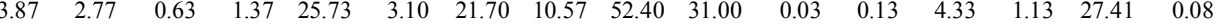

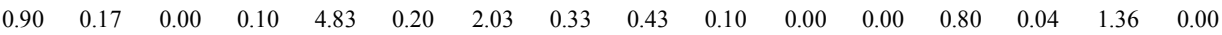

$\begin{array}{llllllllllllllll}0.00 & 0.00 & 0.00 & 0.00 & 0.00 & 0.10 & 0.57 & 0.03 & 0.67 & 0.13 & 0.00 & 0.00 & 0.00 & 0.00 & 0.30 & 0.00\end{array}$

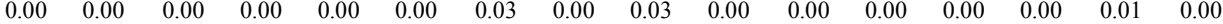

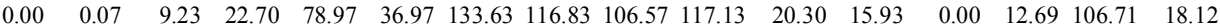

$\begin{array}{llllllllllllllll}0.17 & 0.80 & 0.00 & 0.00 & 0.30 & 0.00 & 0.03 & 0.00 & 0.00 & 0.00 & 0.00 & 0.00 & 0.43 & 0.15 & 0.03 & 0.00\end{array}$

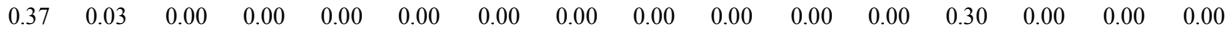

$\begin{array}{llllllllllllllll}0.00 & 0.00 & 0.00 & 0.00 & 0.00 & 0.00 & 0.03 & 0.00 & 0.00 & 0.00 & 0.00 & 0.00 & 0.00 & 0.00 & 0.01 & 0.00\end{array}$

$\begin{array}{llllllllllllllll}3.60 & 1.33 & 0.00 & 0.00 & 2.60 & 0.00 & 0.00 & 0.03 & 0.17 & 0.00 & 0.00 & 0.00 & 3.53 & 0.09 & 0.15 & 0.00\end{array}$

$\begin{array}{llllllllllllllll}3.03 & 9.87 & 18.83 & 14.77 & 43.70 & 27.57 & 44.40 & 59.33 & 37.23 & 24.13 & 0.47 & 2.53 & 4.68 & 18.34 & 38.01 & 1.50\end{array}$

$\begin{array}{llllllllllllllll}0.00 & 0.00 & 0.10 & 0.17 & 0.03 & 1.80 & 0.30 & 0.00 & 0.00 & 0.00 & 14.77 & 13.37 & 0.00 & 0.13 & 0.40 & 14.07\end{array}$

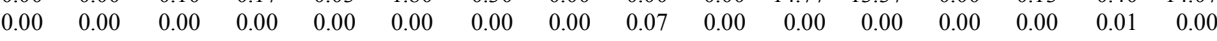
$\begin{array}{llllllllllllllll}0.03 & 0.00 & 0.00 & 0.00 & 0.00 & 0.00 & 0.00 & 0.00 & 0.00 & 0.00 & 0.00 & 0.00 & 0.03 & 0.00 & 0.00 & 0.00\end{array}$

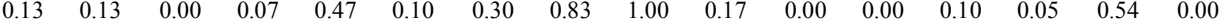

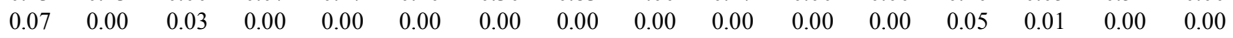
mossambicanus, Metacatharsius sp. to M. zuluanus, Onthophagus ambiguus to Mimonthophagus ambiguus, Onthophagus nanus to Onthophagus sp. 5, Drepanocerus impressicollis to Afrodrepanus impressicollis, Onthophagus fimetarius to Onthophagus sp. $\mathrm{nr}$ fimetarius, Onthophagus $\mathrm{sp}$. $\mathrm{nr}$ bicavifrons to Onthophagus bicavifrons.

**Biogeographical classification from Davis et al. (2002) with slight modifications: $\mathrm{W}=$ Widespread; $\mathrm{EC}=$ East Coastal; $\mathrm{M}=\mathrm{Maputaland}$. 